\title{
THE IMPACT OF PERFORMANCE EVALUATION FORMALITY ON TRUST, WITH TENURE AND TASK UNCERTAINTY AS A CONTROL VARIABLE
}

\author{
Neny Desriani ${ }^{1}$ \\ Pigo Nauli ${ }^{2}$ \\ Anuar Sanusi ${ }^{3}$
}

\begin{abstract}
This study examines the impact of perceived performance evaluation formality on subordinate's trust in supervisor. In addition, this study examines the impact of subordinate's trust in supervisor on budgetary slack. Using a questionnaire survey method with 97 middle and lower level managers in an Indonesian aerospace industry as respondents, with tenure and task uncertainty as a control variable this study shows that formality of the performance evaluation have impact on subordinate's trust in the supervisor.
\end{abstract}

Key Words: Performance Evaluation Formality, Subordinate's Trust in the Supervisor, Tenure, Task Uncertainty.

\footnotetext{
${ }^{1}$ Lecturer in Economic and Business Faculty, IBI Darmajaya Lampung

${ }^{2}$ Lecturer in Economic and Business Faculty, Lampung University

${ }^{3}$ Lecturer in Economic and Business Faculty, IBI Darmajaya Lampung
} 


\section{Introduction}

Studies in various disciplines found that trust is beneficial for organizations although there is no agreement about how the benefit is obtained (Dirks and Ferrin, 2001). In the relationship of supervisor and subordinates, however, generally trust is not considered sufficient for supervisor to control their subordinates' behavior. Therefore, supervisor has usually using formal control like performance evaluation system (Das and Teng, 1998; Malhotra and Muninghan, 2002).

The existing evidence reveals that performance evaluation system has an important potential to affect trust (Malhotra and Muninghan, 2002; Tenbrunsel and Messick, 1999; Coletti et al, 2005). However, there is still a question about which aspect from performance evaluation system that affects trust and how such system affects trust (Hartmann and Slapnicar, 2009). For example, Lau and Buckland (2001) and Lau and Sholihin (2005) found that performance evaluation metrics (either financial or nonfinancial) have impact on trust. However, while Lau and Buckland (2001) found that the effect of financial measures on trust is higher compared to the effect of nonfinancial measures, Lau and Sholihin (2005) found the opposite. To reconcile those findings, Hartmann and Slapnicar (2009) argue that trust is not affected by the metrics of performance measures, but it is affected by the formality of performanve evaluation. Empirically, their findings support their argument.

This study extends the study of Hartmann and Slapnicar (2009). Hartmann and Slapnicar (2009) argued that trust can reduce agency problem, they did not provide empirical evidence. Our study fills this gap by empirically test whether trust reduces the propensity of managers to create budget slack.

Controlling for task uncertainty and tenure we find that formality of the performance evaluation effect subordinate's trust in the supervisor.

The rest of the paper is organized as follows. The next section is theoretical framework and hypotheses development. This will be followed by research method. After research method, the data analysis and research findings of our study will be presented. This paper ends with conclusion, limitation and suggestion for future resarch.

\section{THEORETICAL FRAMEWORK AND HYPOTHESES DEVELOPMENT Performance Evaluation Formality and Trust}

Trust is a fundamental element for all social relationship (Barber, 1983; Barnard, 1938) and particularly collaborative actions (Luhmann, 1979, Parson, 1951). Organizational theorists have noted that coordination (Macaulay, 1963 and Williamson, 1975) and control (Arrow, 1974) depend on trust. In many organizations, since the level of interpersonal trust is still low, particularly between management and employee (Golembiewski and McConkie, 1975), managers use control mechanism (i.e. contract, bureaucratic procedure, legal requirements) to manage their organizations (Fox, 1974). As a legalistic mechanism, control mechanism is typically adopted not only to facilitate an administrative coordination but also to gain symbolic legitimacy which accompanies the use of institutional procedure 
(Meyer, 1983; Sitkin and Roth, 1993) and to gain an appropriate trust level, and importantly for sustainable activity (Shapiro, 1987; Zucker, 1986).

The existing evidence reveals that performance evaluation system has an important potential to affect trust (Malhotra and Munighan, 2002; Tenbrunsel and Messick, 1999; Coletti et al, 2005). The use of formal performance evaluation system would have positive impact on trust, since it enables integrity, honesty, higher accuracy and consistency in the formal performance evaluation than in the informal ones (Hartmann and Slapnicar, 2009). This is not only being consistent with Hopwood (1972), Lau and Buckland (2001), and Lau and Sholihin (2005), but also with other evidences about behavioral impact from implicit and subjective performance measures (Hartmann, 2007; Moers, 2005).

Consistent with Hartmann and Slapnicar (2009), in this study, the term of performance evaluation formality refers to the level of perceived performance evaluation formality, that is agent perception toward formality level being applied by the principal when evaluating agents. Principal who uses formal performance evaluation is a principal that explains performance target explicitly, measures performance with a clear metric set, and provides reward based on clear allocation rules. Those three phases of performance evaluation process is assumed as three dimension of performance evaluation system that determined the overall formality.

Overall, we argue that the use of formal performance evaluation system would have positive impact on trust, since it enables integrity, honesty, higher accuracy and consistency in the formal performance evaluation. The hypothesis being tested is:

\section{H1: There is positive impact of perceived performance evaluation formality level toward trust}

\section{RESEARCH DESIGN}

This study was conducted using aquestionnaire survey method by distributing the questionnaires to lower and middle level managers in an aerospace company in Indonesia. The reason for choosing survey method is due to two considerations. First, there is no public data archive about constructs used in this study. Second, study about fairness and trust is usually assumed as a privacy, which requires data collection being anonymous. This is easily achieved with survey method (Hartmann and Slapnicar, 2009).

This study was conducted on single company with some reasons. First, by focusing on one company enabled us to obtain very detailed data both individual and other qualitative information to complete quantitative findings (Elvira and Graham, 2002). In this case, we could relate detailed data on performance evaluation formality from individual employee. Second, company consists of 28 divisions, thus providing the possibility of significant variation from the variables examined. Moreover, this study is done on individual level. Third, the observed company is the only company in Indonesia which operated in aerospace industry.

To select samples we use purposive sampling with the following criteria: (1) the samples had served in their current position minimal 1 year to ensure their familiarity to the 
performance evaluation system, (2) they have supervisor who evaluates their performance, (3) their performance has been evaluated.

\section{Variable Measurement}

We measured performance evaluation system formality with the instrument developed by Hartmann and Slapnicar (2009). This instrument measures performance evaluation system as a latent construct. This construct was developed as having three different formality subsystems as follow: 1) target setting formality is measured using two items asking whether target setting has been made by principal either in written form and quantitatively (more formal) or vice versa, 2) performance measurement formality is measured using two items on how the principal making performance evaluation, based on either objective information and qualitatively (less formal), and 3) rewarding formality is measured with four indicator items that reveal the reward determination objectivity. The overall instrument is stated on Likert Scale 5 Point with numerical scaling getting close to scale 1 is less formally and conversely getting close to scale 5 means more formally.

Trust to the supervisor (principal) was measured with the instrument developed by Read (1962). This instrument measured trust by asking subordinates (agent) about the extent to which they viewed that their supervisor tends to take action by considering the subordinates' interest.

We include two control variables; tenure and task uncertainty. The first control variable was measured with the duration of respondent have been in that managerial position. This variable is control toward time effect of trust (Gibbs et al, 2004). The second control variable is measured with the instrument developed by Withey, Daft, and William (1983). That variable is purposed to control the potential uncertainty that may affect performance measurement use.

\section{DATA ANALYSIS AND FINDINGS}

\section{Research Participants}

The returned questionnaires were 108 from 170 questionnaires sent to the targeted respondents (response rate of $63.53 \%$ ). However, not all returned questionnaires can be analyzed. From 108 returned questionnaires, there are only 97 questionnaires can be used in this study. Six questionnaires could not be used due to incompleteness, three questionnaires was filled with the same number of all items, and two questionnaires did not satisfy the sampling criteria because the tenure less than one year.

\section{Preliminary Analysis}

Prior to hypothesis testing, we conducted a preliminary analysis to see the sample characteristics using demography analysis, descriptive analysis, and respondent's responsibility area analysis. Most of respondents are male (90\%), and the rest is female. This fits the specialty of technology company in general and aerospace industry in particular, where the majority of employees are male. Most employees are 50 to 55 years old $(53 \%)$. The working experiences majority for 21 to 30 years (79\%), and all have been 
working in the company for 10 years, except one person that have been working in the company for 5 years. The tenure in the existing position majority for 1 to 5 years $(71 \%)$ and mostly have subordinates less than 5 people $(53 \%)$.

The minimum age of the sample is 29 years old and maximal 55 years old, with the sample's average age of 49.55 years old. The respondents have been working in the company minimal for 5 years and the longest is 33 years, by the average working experience is 24.25 years. The tenure of sample is 1 year for the shortest and 20 years for the longest, with the average tenure of 4.78 years. If it viewed from the responsibility area, the sample dispersed in 23 divisions from all 28 divisions existed in the company, with the different working variation. Of all research sample, 75 persons $(77.32 \%)$ is lower level manager, and 22 persons (22.68 \%) are middle level manager.

\section{Results}

To test the hypothesis we use SmartPLS 2.0 software. Using PLS, we can examine two matters: measurement and structural model. Measurement model is used to test the convergent and discriminant validity of each indicator. The reliability in PLS is tested by evaluating the Cronbach's Alpha and Composite Reliability. Cronbach's Alpha measures the lower limit of reliability value of a construct, whilst the Composite Reliability measures the actual reliability value of a construct. But, in PLS, Composite Reliability is considered to be better in estimating the internal consistency of a construct (Werts et al, 1974). The structural model is used to test the hypotheses using bootstrapping function.

\section{Result and Interpretation of Measurement (Outer) Model Testing}

The summary table of measurement model testing result (see Table 1) showing that all indicators have satisfied AVE score criteria and good factor loading (>0.4). It means that all construct have satisfied the convergent validity test.

The cross loading table (table 2) reveals that each indicator in a variable has difference with the indicator in other variable. It is indicated by the loading score that higher in its own construct. The discriminant validity table (Table 3) showing that the root square of AVE is higher than the latent variable correlation. Indicated by the numbers on the diagonal section that symbolized with bold number, it has a higher value than is not in diagonal section. This is shown that all variables have satisfied discriminant validity criteria.

Those results indicate that all items are on the proposed variable. As overall, it can be concluded that the measure that be used is valid, both of convergent and discriminant validity.

As can be seen in the table of measurement model test result (See table 1), the Cronbach's Alpha for variable interpersonal trust (TRUST) is larger than 0.7, but variable of formality level (FORM) have Cronbach's Alpha less than 0.7. However, since in PLS path modeling, composite reliability is valued better in estimating the internal consistency in a construct (Werts et al, 1974), thus even the Cronbach's Alpha is less than 0.7, but the Composite Reliability is more than 0.7, then it still be assumed to be reliable. Consequently, it can be concluded that the instrument used in this study is reliable. 


\section{Result and Interpretation of Structural (Inner) Model Testing}

Having testing to the measurement (outer) model by using PLS Algorithm function, the further step is conduct examination to the structural (inner) model. Using the significance level of 0.05 , the result of each hypothesis is as follow (see table 4). First hypothesis (H1) which stated that there is positive impact of perceived performance evaluation formality level on trust, is supported.

\section{IMPLICATIONS AND LIMITATIONS}

This study extends the study of Hartmann and Slapnicar (2009) about the impact of formality level of performance evaluation on subordinate's trust to the principal. The results indicate that formality level of performance evaluation has a positive impact on subordinate's trust to the principal. This study result implied that the formality level of performance evaluation is a relevant characteristics to create a subordinate's trust to the principal.

Some limitations in this study are described as follow. First, participants used in this study are professionals from one company and one industry, Consequently, the results cannot be generalized. Second, this study used survey approach; some inherent limitation of this method must be recognized. Future study may examine the topic using different approach, such as experiment.

\section{REFERENCES}

Arrow K. 1974. The Limits of Organization. New York: Norton. 173 pp.

Barber, B. 1983, The Logic and Limits of Trust, New Brunswick, NJ: Rutgers University Press.

Barnard, Chester I., The Functions of the Executive, Harvard University Press, Cambridge, Massachusetts, 30 anniversary edition 1974, 1938.

Coletti, A. L., Sedatole, K. L., dan Towry, K. L. 2005. The effect of control systems on trust in collaborative environments. The Accounting Review, 80, 477-500.

Cooper, Donald R., dan Pamela S. Schindler. Business Research Methods, 9 th Ed. New York:McGraw-Hill

Das, T. K., dan Teng, B. S. 1998. Between trust and control: Developing confidence in partner cooperation in alliances. Academy of Management Review, 23, 491-512.

Dirks, Kurt T. dan Donald L. Ferrin 2001. The Role of Trust in Organizational Settings. Organization Science, Vol. 12, No. 4 Jul. - Aug., 2001, pp. 450-467

Elvira, Marta M. dan Mary E. Graham. 2002. Not Just a Formality: Pay System Formalization and Sex-Related Earnings Effects. Organization Science, Vol. 13, No. 6 Nov. - Dec., 2002, pp. 601-617

Fox A. 1974. Beyond Contract: Power and Trust Relations. London: Faber dan Faber. 371 pp. 
Gibbs, M., Merchant, K. A., Van der Stede, W. A., dan Vargus, M. E. 2004. Determinants and effects of subjectivity in incentives. The Accounting Review, 79, 409-436.

Golembiewski, R. T. and M. McConkie 1975, "The Centrality of Interpersonal Trust in Group Processes," in C. L. Cooper Ed., Theories of Group Processes, London: John Wiley dan Sons, 131-185.

Hartmann, Frank dan Sergeja Slapnicar. 2009. How formal performance evaluation affects trust between superior and subordinate managers. Accounting, Organizations and Society 342009 $722-737$.

Hopwood, A. G. 1972. An empirical study of the role of accounting data in performance evaluation. Journal of Accounting Research, 10, 156-182.

Lau, C. M., dan Buckland, C. 2001. Budgeting - Role of trust and participation: A research note. ABACUS, 37, 369-388.

Lau, C. M., dan Shohilin, M. 2005. Financial and nonfinancial performance measures: How do they affect job satisfaction. British Accounting Review, 37, 389-413.

Macaulay, Stewart. 1963. Non-contractual Relations in Business: A Preliminary Study. American Sociological Review 28:55-67.

Malhotra, D., dan Munighan, J. K. 2002. The effects of contracts on interpersonal trust. Administrative Science Quarterly, 47, 534-559.

Meyer, J. W. 1983. Organizational factors affecting legalization in education. In J. W. Meyer dan W. R. Scott (Eds.), Organizational environments: Ritual and rationality: 217-232. San Francisco: Jossey-Bass.

Moers, F. 2005. Discretion and bias in performance evaluation: The impact of diversity and subjectivity. Accounting, Organizations and Society, 30, 67-80.

Read, W. H. 1962. Upward communication in industrial hierarchies. Human Relations, 15, 3-15.

Shapiro,S . P. 1987. The Social Control of Impersonal Trust. American Journal of Sociology 933:623-58.

Sitkin, Sim B., dan N. L. Roth. 1993. Explaining the Limited Effectiveness of Legalistic "Remedies" for Trust/Distrust. Organizational Science 4 (3):367-92.

Tenbrunsel, A. E., dan Messick, D. M. 1999. Sanctioning systems, decision frameworks, and cooperation. Administrative Science Quarterly, 44, 684-707.

Werts, C.E., Linn, R.L., dan Joreskog, K.G.(1974). Intraclass reliability estimates: Testing structural assumptions. Educational and Psychological Measurement, 34(1), 25-33.

Williamson, 0. E. 1975. Markets and hierarchies: Analysis and antitrust implications. New York: Free Press.

Withey, M., Daft, R. L., dan William, H. C. 1983. Measures of Perrow's work unit technology: An empirical assessment and a new scale. The Academy of Management Journal, 261, 45-63.

Zucker, Lynne G. 1986. Production of Trust: Institutional Sources of Economic Structure, 18401920. Research in Organizational Behavior, e d. B. M. Staw and L. L. Cummings, 8:53-111. Greenwich, Conn.: JAI 


\section{APPENDIX}

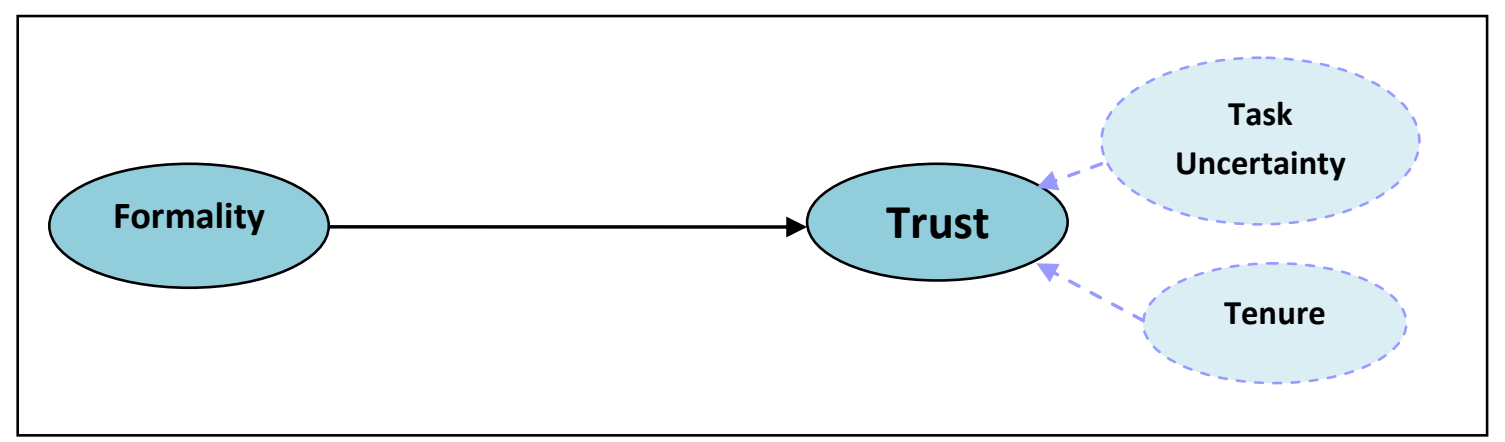

Figure 1 Research Mode

Table 1

Summary of Measurement Model

\begin{tabular}{|l|l|l|l|l|l|}
\hline \multicolumn{1}{|c|}{ Variable } & Indicators & $\begin{array}{c}\text { Outer } \\
\text { Loading }\end{array}$ & AVE & $\begin{array}{c}\text { Cronbach } \\
\text { Alpha }\end{array}$ & $\begin{array}{c}\text { Composite } \\
\text { Reliability }\end{array}$ \\
\hline Degree of Formality & FormPM & 0,796683 & 0,567655 & 0,621536 & 0,797251 \\
& FormRew & 0,728537 & & & \\
\cline { 2 - 3 } & FormTS & 0,733141 & & & \\
\hline \multirow{3}{*}{ Task Uncertainty } & tun1 & 0,782348 & 0,61955 & 0,699938 & 0,83003 \\
\cline { 2 - 3 } & tun2 & 0,809342 & & & \\
\cline { 2 - 3 } & tun3 & 0,769139 & & & 1 \\
\hline Tenure & ten & 1 & 1 & 1 & 0,839746 \\
\hline \multirow{5}{*}{ Trust } & it1 & 0,754995 & 0,568395 & 0,744449 & \\
\cline { 2 - 3 } & it2 & 0,83827 & & & \\
\cline { 2 - 3 } & it3 & 0,72276 & & & \\
\cline { 2 - 3 } & it4 & 0,691726 & & & \\
\hline
\end{tabular}

Table 2 Cross Loadings

\begin{tabular}{|l|c|r|r|r|}
\hline & FORM & TRUST & Tenure & $\begin{array}{c}\text { Task } \\
\text { Uncertainty }\end{array}$ \\
\hline FormPM & 0,796683 & 0,366495 & 0,012827 & 0,193327 \\
\hline FormRW & 0,728537 & 0,292881 & 0,164687 & 0,255035 \\
\hline FormTS & 0,733141 & 0,396905 & $-0,08698$ & 0,274643 \\
\hline it1 & 0,469811 & 0,754995 & $-0,19123$ & 0,400605 \\
\hline it2 & 0,389126 & 0,83827 & $-0,16284$ & 0,434491 \\
\hline it3 & 0,301465 & 0,72276 & $-0,26683$ & 0,501081 \\
\hline it4 & 0,247934 & 0,691726 & $-0,11514$ & 0,34372 \\
\hline ten & 0,027847 & $-0,24734$ & 1 & $-0,105791$ \\
\hline tun1 & 0,25068 & 0,543793 & $-0,10639$ & 0,782348 \\
\hline tun2 & 0,28609 & 0,402338 & $-0,12792$ & 0,809342 \\
\hline tun3 & 0,21976 & 0,3367 & 0,005512 & 0,769139 \\
\hline \multicolumn{7}{|c|}{ Source:Output SmartPLS }
\end{tabular}


Tabel 3

Discriminant Validity

\begin{tabular}{|l|r|r|r|r|}
\hline & \multicolumn{1}{|c|}{ FORM } & \multicolumn{1}{c|}{ TRUST } & \multicolumn{1}{c|}{ TUN } & TEN \\
\hline FORM & $\mathbf{0 , 7 5 3 4 3}$ & & & \\
\hline TRUST & 0,478652 & $\mathbf{0 , 7 5 3 9 2}$ & & \\
\hline $\begin{array}{l}\text { Task } \\
\text { Uncertainty }\end{array}$ & 0,322498 & 0,560229 & $\mathbf{0 , 7 8 7 1 1}$ & \\
\hline Tenure & 0,027847 & $-0,2447335$ & $-0,105791$ & $\mathbf{1}$ \\
\hline
\end{tabular}

Source:Output SmartPLS

Table 4

Summary of Structural Model

\begin{tabular}{|l|c|c|c|c|}
\hline Hyphotesis & Path & Coeffisient & T-Statistics & Significant \\
\hline H1 & FORM $\rightarrow$ IT & 0,340885 & 4,08512 & Yes \\
\hline
\end{tabular}

